\title{
ANALISIS KOMPETENSI PRODUK UNGGULAN DAERAH PADA BATIK TULIS DAN CAP SOLO DI DATI II KOTA SURAKARTA
}

\author{
Daryono Soebagiyo ${ }^{1}$ \\ M. Wahyudi ${ }^{1}$ \\ ${ }^{1}$ Fakultas Ekonomi Universitas Muhammadiyah Surakarta \\ E mail: dsoebagyo@yahoo.com
}

\begin{abstract}
This research concerning local prominent product competency of 'batik tulis' and 'batik cap' in Surakarta. Two kinds of these batik are production of small and middle scale industry (IKM Batik) where IKM Batik has became one of economy prime activator in Surakarta. In this research, writers apply research methods as follows: Bayes approach technique for getting priority prominent product rank, Analytical Hierarchy Process (AHP) by using Expert Choice Software, with aim to know prominent competency of IKM in Surakarta, and Value Chain Economic Analysis started with chain mapping to priority prominent product which appertained as main rank. Research result indicates that competency approach in local industrial development relevant enough for increasing local competitiveness and finally increasing national competitiveness. It can be happened considering that competency approach try to exploit local excess and excellence uniquely.
\end{abstract}

Keywords: bayers method, analytical hierarchy process, chain mapping

\section{PENDAHULUAN}

Kebijakan pembangunan industri jangka menengah saat ini (2004-2009) diarahkan pada pengembangan dan penumbuhan kluster-kluster industri, yang sementara ini berjumlah sepuluh kelompok industri, yaitu: (i) industri makanan dan minuman, (ii) industri pengolahan hasil laut, (iii) industri tekstil dan produk tekstil, (iv) industri alas kaki, (v) industri kelapa sawit, (vi) industri barang kayu (termasuk rotan), (vii) industri karet dan barang karet, (viii) industri pulp dan kertas, (ix) industri mesin listrik dan peralatannya, (x) serta industri petrokimia. Dalam kebijakan pembangunan industri, pengembangan sepuluh kluster industri inti dilakukan secara komprehensif dan integratif, yang didukung secara simultan dengan pengembangan industri terkait (related industries) dan industri penunjang (supporting industries). Dalam pelaksanaannya, pembangunan industri dimaksud seharusnya juga dilakukan dengan sinergi dan terintegrasi dengan pembangunan sektor lain seperti pertanian dan jasa. Dukungan kelembagaan juga harus bersinergi dengan dengan koordinasi kelembagaan terkait lainnya.

Dengan mempertimbangkan kondisi pembangunan industri, baik di tingkat nasional maupun daerah, dan dalam rangka peningkatan daya saing, maka pembangunan industri dilaksanakan dengan melakukan 
sinergi antara perencanaan di tingkat nasional atau pusat dan perencanaan di tingkat daerah. Hal ini dilakukan dengan dua pendekatan sekaligus, yaitu pendekatan top down dan pendekatan bottom up. Pendekatan top down pembangunan industri direncanakan dengan memperhatikan prioritas yang ditentukan secara nasional dan diikuti oleh partisipasi daerah. Hal ini biasa dikenal dengan pembangunan berdasarkan disain (by design) nasional. Pendekatan bottom up dilakukan dengan penetapan kompetensi inti yang merupakan keunggulan daerah. Penggunaan kompetensi inti sebagai unggulan daerah ini dimaksudkan agar daerah memiliki daya saing dan meningkatkan daya saingnya.

Praktek perencanaan dengan dua pendekatan ini tercermin dari pelaksanaan rencana pembangunan industri. Berdasarkan disain nasional, kebijakan industri secara nasional dilakukan dengan menentukan industri prioritas, yaitu dikenalkannya 32 industri prioritas dengan pendekatan kluster. Kemudian, secara bottom up, pemerintah telah secara aktif melakukan sosialisasi dan mengajak daerah berpartisipasi dalam pembangunan kompetensi pada setiap daerah prioritas. Penggunaan kompetensi dalam pembangunan industri daerah cukup relevan untuk tujuan peningkatan daya saing daerah dan akhirnya juga peningkatan daya saing nasional. Hal ini dapat terjadi mengingat bahwa pendekatan kompetensi berusaha mengeksploitasi kelebihan dan keunggulan daerah secara unik. Kompetensi di sini didefinisikan sebagai kumpulan keterampilan dan teknologi yang memungkinkan suatu organisasi dapat menyediakan manfaat tersendiri secara unik kepada pelanggannya. Hal ini diterjemahkan dalam pembangunan industri daerah dengan mencoba melakukan eksploi- tasi sumberdaya dan kemampuan organisasi secara unik. Keunikan ini merupakan nilai tersendiri yang tidak dimiliki daerah lain, dan oleh karena itu akan menjadi keuntungan bagi daerah yang memilikinya. Penerapan kompetensi secara nasional dapat diterjemahkan dengan memperkenalkan satu produk unik pada setiap daerah yang berbeda. Hal ini dilakukan agar seluruh sumberdaya dan kemampuan yang dimiliki daerah tersebut terfokus pada upaya untuk menciptakan kompetensi yang bersifat unik.

Sesuai dengan sumber dan perkembangan konsep kompetensi, maka dalam usaha membangun kompetensi (baik berupa produk, layanan atau komoditi) seharusnya memperhatikan kriteria-kriteria yang relevan dengan kebutuhan peningkatan daya saing, yaitu keunikan (dan sulit ditiru), kemampuan memberi manfaat lebih, atau kemampuan memberi keuntungan dengan korbanan yang lebih efisien.

Pada konteks daerah, pemilihan kompetensi seharusnya mempertimbangkan kondisi daerah dengan tetap memperhatikan kriteria persaingan seperti: adanya nilai tambah yang tinggi, adanya sifat yang unik, adanya keterkaitan dan peluang untuk bersaing di pasar luar daerah (bahkan internasional). Dengan kata lain, pemilihan dan penentuan kompetensi seharusnya memberi dampak yang besar dalam memberi stimulus perekonomian daerah. Yang lebih penting lagi hal tersebut harus dilakukan dengan memperhatikan kemampuan sumberdaya daerah.

Surakarta merupakan kota yang memiliki banyak IKM, di mana IKM di Surakarta adalah sebagai penggerak utama ekonomi masyarakat. Data IKM Surakarta pada tahun 2007 mencapai 80 persen jumlah usaha dengan kontribusi penyerapan tenaga kerja 
mencapai lebih dari 95 persen. Untuk usaha menengah di Surakarta terdapat kurang lebih 85 unit usaha menyerap 10.608 orang dengan nilai investasi sebesar Rp.45.870.748.000. Usaha kecil sebanyak 1.061 unit menyerap tenaga kerja 24.954 orang dengan nilai investasi sebesar Rp.57.895.790.000 dan sektor informal meliputi 4.070 unit usaha digerakkan oleh 12.055 tenaga kerja dengan investasi sebesar Rp.15.071.040.000 (Tabel 1)

Perkembangan sektor industri di kota

Tabel 1. Data Industri Kota Surakarta Tahun 2006

\begin{tabular}{cccccc}
\hline No. & Uraian & Tenaga Kerja & Nilai Investasi & Nilai Produksi & Jumlah Unit Usaha \\
\hline 1. & Industri Kecil & 24.954 & 57.895 .790 & 4.239 .889 .800 & 1061 \\
2 & Industri menengah & 7.560 & 45.870 .748 & 1.127 .798 .350 & 85 \\
3. & Industri besar & 10.608 & 297.795 .960 & 1.017 .089 .000 & 41 \\
4. & Non Formal & 12.055 & 15.071 .040 & 1.592 .397 .420 & 4.070 \\
& Jumlah & 55.177 & 416.633 .538 & 7.977 .174 .570 & 5.257 \\
\hline
\end{tabular}

Sumber: Rencana Pengembangan Industri di Surakarta, Disperindag. 2007.

Tabel 2. Produk IKM Kota Surakarta

\begin{tabular}{|c|c|c|c|c|c|c|}
\hline No & Nama Produk/Industri & $\begin{array}{c}\text { Nilai } \\
\text { Produksil } \\
\text { tahun }(000)\end{array}$ & Investasi & $\begin{array}{l}\text { Unit } \\
\text { Usaha }\end{array}$ & $\begin{array}{c}\text { Jumlah } \\
\text { Tenaga Kerja }\end{array}$ & $\begin{array}{c}\text { Kapasitas } \\
\text { Produksil } \\
\text { tahun }\end{array}$ \\
\hline 1 & Alat Musik & 270.225 & 138.380 .000 & 2 & 68 & 3.603 \\
\hline 2 & Batik dan Produk Batik & 48.008 .448 .000 & 672.333 .340 & 7 & 108 & 480.084 .480 \\
\hline 3 & Bengkel & 480.334 .240 & 772.350 .000 & 13 & 91 & 12.008 .356 \\
\hline 4 & Elastik & 120.000 & 104.000 .000 & 1 & 10 & 24.000 \\
\hline 5 & Fiber Glass & 1.000 & 30.000 .000 & 1 & 5 & 200 \\
\hline 6 & Foto Stodio & 4.400 & 40.000 .000 & 1 & 4 & 220 \\
\hline 7 & Handicraft & 997.800 & 389.837 .000 & 5 & 20 & 16.630 \\
\hline 8 & Kapur Semut & 30.000 & 16.000 .000 & 1 & 2 & 60.000 \\
\hline 9 & Kaset & 33.000 & 21.500 .000 & 1 & 1 & 3.000 \\
\hline 10 & Kemasan & 188.000 & 32.040 .000 & 3 & 11 & 37.600 \\
\hline 11 & Kimia & 1.000 & 24.500 .000 & 1 & 41 & 2 \\
\hline 12 & Kosmetik & 1.095 .000 & 152.232 .500 & 3 & 12 & 73.000 \\
\hline 13 & Logam & 12.720 & 53.415 .000 & 2 & 8 & 636 \\
\hline 14 & Makanan & $180.544 .134,5$ & 3.386 .740 .000 & 37 & 142 & 361.088 .269 \\
\hline 15 & Mebel & 2.789 .000 & 2.048.751.000 & 5 & 105 & 5.578 \\
\hline 16 & Mesin Industri & 342.000 & 175.600 .000 & 3 & 25 & 456 \\
\hline 17 & Obat-obatan & 2.750 .000 & 50.000 .000 & 1 & 5 & 50.000 \\
\hline 18 & Pengolahan Hasil Bumi & 6.300 & 40.000 .000 & 1 & 4 & 180 \\
\hline 19 & Percetakan & 9.152 .955 & 3.220 .009 .500 & 23 & 194 & 9.152 .955 \\
\hline 20 & Plastik & $6.394 .012,5$ & 8.802 .650 .000 & 7 & 1.088 & 852.535 \\
\hline 21 & Pupuk & 7.500 & 60.000 .000 & 1 & 3 & 100 \\
\hline 22 & Rokok Kretek & 245.000 & 40.650 .000 & 1 & 6 & 700.000 \\
\hline 23 & Shuttle Cock & 96.000 & 38.800 .000 & 1 & 5 & 96.000 \\
\hline 24 & Tekstil dan Produk Tekstil & 25.271 .415 .000 & 663.385 .000 & 10 & 2.523 & 336.952 .200 \\
\hline 25 & Timbangan & 72.750 & 251.560 .000 & 4 & 34 & 4.850 \\
\hline 26 & Transportasi & 22.000 & 40.000 .000 & 1 & 7 & 400 \\
\hline
\end{tabular}


Surakarta, di masa datang dititikberatkan pada industri kecil dan kerajinan rakyat. Data Desperindag yang dikumpulkan saat prasurvei yang dilakukan oleh peneliti (2007) menunjukkan bahwa jumlah industri kecil di kota Solo mencapai 3.821 industri, sedang industri besar dan menengah ada 56 industri dengan tenaga kerja yang terserap berjumlah 38.765 orang. Dari beberapa jenis industri yang ada di kota Surakarta (Solo) terdapat produk unggulan yaitu; usaha batik dan konveksi Beberapa produk komoditi Industri Kecil Menengah (IKM) tersebut terlihat dalam Tabel 2.

Dengan melihat persoalan tersebut maka, penelitian ini akan mencoba menganalisis Kompetensi Unggulan Daerah pada Produk Batik Tulis dan Batik Cap Solo di Dati II Kota Surakarta.

\section{METODE PENELITIAN}

Dalam penelitian ini diketengahkan bahwa kompetensi IKM daerah Kota Surakarta adalah keunggulan yang dimiliki daerah yang unik meliputi aspek Keterampilan Manusia, Sumber Daya Alam, Lingkungan, Budaya, dan Prospek Pasar, baik untuk produk primer maupun produk olahan.

Adapun ciri-ciri kompetensi inti daerah terdiri dari 3 yaitu:

1. Memiliki akses potensial ke berbagai pasar - kompetensi daerah harus dapat mengembangkan produk atau jasa baru

2. Kompetensi daerah harus menciptakan kontribusi nyata untuk mendapatkan manfaat produk akhir.

3. Kompetensi daerah seharusnya memiliki sesuatu yang sulit ditiru oleh kompetitor lain/daerah lain, dengan kata lain bersifat unik.
Metode dan alat analisis yang dipergunakan dalam pengkajian kompetensi unggulan IKM Kota Surakarta dilakukan dengan menggunakan teknik pendekatan:

a. Metode Bayes, guna memperoleh peringkat produk unggulan prioritas.

b. Analytical Hierarchy Process (AHP) dengan mengaplikasikan Software Expert Choice, yang bertujuan untuk mengetahui Kompetensi Unggulan IKM Daerah Kota Surakarta

c. Analisis Ekonomi Rantai Nilai, yang dimulai dengan melakukan pemetaan rantai (chain map) atas produk unggulan priotitas yang tergolong sebagai peringkat utama, dengan menggambarkan secara garis besar tahapan mulai dari input hingga pemasaran produk sampai ke tangan konsumen. Kemudian masingmasing mata rantai nilai diidentifikasi apa yang menjadi kekuatan atau kompetensinya. Untuk selanjutnya dikuantifikasi dan dinilai Analisis Ekonomi Rantai Nilainya.

\section{HASIL PENELITIAN DAN PEMBAHASAN}

\section{Profil Industri Kecil dan Menengah}

Usaha kecil dan menengah idealnya memang membutuhkan peran dan campur tangan dari pemerintah dalam peningkatan kemampuan bersaing. Sungguhpun demikian, yang perlu diperhatikan adalah bahwa kemampuan di sini bukan dalam arti kemampuan untuk bersaing dengan usaha/industri besar, tetapi lebih pada kemampuan untuk memprediksi lingkungan usaha dan kemampuan untuk mengantisipasi kondisi lingkungan tersebut. Terdapat karakteristik khusus dari suatu 
produk yang cocok untuk industri kecil dan ada kelompok produk yang cocok untuk industri besar. Industri kecil tidak akan mampu bertahan pada kelompok produk yang cocok untuk industri besar. Dan sebaliknya, industri besar tidak akan tertarik untuk masuk dan bersaing dalam kelompok produk yang cocok untuk industri kecil, karena dengan pertimbangan efisiensi skala usaha. (Stanley dan Morse, 1965).

Peran kebijakan pemerintah bukan saja pada pemberian modal, tetapi lebih pada membina kemampuan industri kecil dan membuat suatu kondisi yang mendorong kemampuan industri kecil dalam mengakses modal atau dengan kata lain, pemerintah harus membina kemampuan industri kecil dalam menghitung modal optimum yang diperlukan, kemampuan menyusun suatu proposal pendanaan ke lembaga-lembaga pemberi modal, serta mengeluarkan kebijakan atau peraturan yang lebih memihak industri kecil dalam pemberian kredit. Menurut Haeruman (2000), bahwa tantangan bagi dunia usaha, terutama pengembangan IKM, mencakup aspek yang luas, antara lain;(1) Peningkatan kualitas SDM dalam hal kemampuan manajemen, organisasi dan teknologi, (2) Kompetensi kewirausahaan, (3) Akses yang lebih luas terhadap permodalan, (4) Informasi pasar yang transparan, (5) Faktor input produksi lainnya, dan (6) Iklim usaha yang sehat yang mendukung inovasi, kewirausahaan dan praktek bisnis serta persaingan yang sehat.

Namun permasalahan yang dihadapi oleh pemerintah dalam upaya pengembangan wirausaha industri kecil menengah yang tangguh adalah pemilihan dan penetapan strategi (program) untuk dua kondisi yang berbeda. Kondisi yang dimaksud adalah: (i) mengembangkan pengusaha yang sudah ada supaya menjadi tangguh, atau (ii) mengembangkan wirausaha baru yang tangguh.

Strategi (program) pengembangan untuk kedua kondisi tersebut haruslah berbeda (spesifik). Bahkan strategi pengembangan untuk pengusaha yang sudah ada pun tidak dapat dilakukan dengan "penyeragaman". Apa yang disebutkan oleh Haeruman di atas adalah kondisi yang digeneralisasi. Tiap jenis usaha, bahkan tiap pengusaha pada jenis yang sama akan mempunyai permasalahan yang berbeda. Diperlukan suatu studi yang matang dan mendalam (diagnosis) untuk mengetahui apa sebenarnya permasalahan yang dihadapi oleh industri kecil menengah yang akan dibina. Tanpa studi dan perencanaan yang matang, maka usaha program pengembangan (meski dengan niat yang baik) akan menemui banyak kendala, misalnya: (a) salah sasaran, (b) sia-sia (mubazir), dan (c) banyak manipulasi dalam implementasinya. Kasus munculnya koperasi dan industri kecil menengah "dadakan" ketika diluncurkan kebijakan kredit tanpa bunga (kredit dengan bunga yang rendah), dapat dijadikan salah satu contoh kegagalan usaha pengembangan insustri kecil menengah yang dilakukan pemerintah.

\section{Keunggulan Berbasis Kompetensi}

Perkembangan terbaru tentang paradigma perusahaan atau organisasi yang berbasis sumberdaya adalah adanya fokus pada suatu basis, sesuai yang melampaui asset-asset tangible dan intangible, tentang keunggulan berbasis sumberdaya, yaitu kompetensi. Dalam kerangka ini, perusahaan fokus pada kompetensi inti. Suatu kompetensi inti dapat didefinisikan sebagai seperangkat ketrampil- 
an dan teknologi yang terintegrasi. Suatu kompetensi perusahaan bukan suatu hal yang sama dengan ketrampilan individu personelnya, tetapi merupakan integrasi dari keterampilan-keterampilan yang ada. Hal ini juga tidak sama dengan sumberdaya, sebab kompetensi lebih merupakan suatu asset. Perusahaan, jaringan distribusi, brand kesemuanya merupakan asset (dan sumberdaya), Sungguhpun demikian, suatu kemampuan khusus untuk mengelola perusahaan, jaringan distribusi, atau brand adalah merupakan kompetensi.

Suatu kompetensi dapat dikatakan disini apabila memenuhi syarat syarat tertentu. Yang utama, syarat untuk kompetensi adalah keterbukaan terhadap pasar baru, kemungkinan-kemungkinan baru, sifat yang adaptif. Manager suatu perusahaan yang memiliki suatu kompetensi harus berpikir tentang bagaimana seperangkat ketrampilan yang terintegrasi diterapkan pada domain-domain produk baru. Oleh karena itu pandangan yang berbasis kompetensi berangkat dari fokus pada strategi level bisnis dan mulai menghadapi strategi level korporasi, dan menentukan jenis usaha (bisnis) yang tepat.

\section{Gambaran Industri Kecil dan Menengah}

\section{Kota Solo}

Kota Solo adalah kota yang memiliki banyak industri kecil menengah, sebagai penggerak utama ekonomi masyarakat, yang memberi Kontribusi besar bagi pendapatan daerah dan memegang peranan penting bagi pertumbuhan perekonomian daerah. (Tabel 3)

Usaha/Industri Kecil dan Menengah di kota Solo yang banyak jumlahnya dan macam produknya. Yang tercatat di data laporan Disperindag Kota Solo terdapat 26 macam produk. Prioritas. Tetapi dari 26 macam produk prioritas tersebut terdapat 7 produk yang potensial dapat dikembangkan di Kota Solo.

Industri kecil menengah yang paling menonjol yang diutamakan bagi Kota Surakarta apabila ditilik dari besarnya nilai produksi dan besarnya nilai investasi tentunya adalah Batik dan Produk Batik, Tekstil dan Produk Tekstil serta Makanan yang menghasilkan berbagai aneka makanan dan makanan ringan. Ketiga produk ini merupakan trade mark bagi Kota Surakarta atau Solo, dari sisi Produksi yang dihasilkan daerah (Tabel 4)

Suatu studi penelitian yang pernah dilakukan oleh penulis yang sama untuk menen-

Tabel 3. Produk Industri Kecil Menengah di Kota Solo

\begin{tabular}{|c|c|c|c|c|c|}
\hline No & Nama Produk/Industri & $\begin{array}{l}\text { Nilai Produksil } \\
\text { tahun }\end{array}$ & Investasi & $\begin{array}{l}\text { Unit } \\
\text { Usaha }\end{array}$ & $\begin{array}{c}\text { Jumlah } \\
\text { Tenaga Kerja }\end{array}$ \\
\hline 1 & Batik dan Produk Batik & 48.008 .448 .000 .000 & 672.333 .340 & 7 & 108 \\
\hline 2 & Logam/Besi & 12.720 .000 & 53.415 .000 & 2 & 8 \\
\hline 3 & Makanan & 180.544 .134 .500 & 3.386 .740 .000 & 37 & 142 \\
\hline 4 & Mebel & 2.789 .000 .000 & 2.048 .751 .000 & 5 & 105 \\
\hline 5 & Percetakan & 9.152 .955 .000 & 3.220 .009 .500 & 23 & 194 \\
\hline 6 & Plastik & 6.394 .012 .500 & 8.802 .650 .000 & 7 & 1.088 \\
\hline 7 & Tekstil dan Produk Tekstil & 25.271 .415 .000 .000 & 663.385 .000 & 10 & 2.523 \\
\hline
\end{tabular}

Sumber: Disperindag Kota Solo 2006 
tukan Kriteria dan kompetensi Kota Solo dengan melihat produk-produk potensial yang dapat dikembangkan bagi daerah kota Solo dari 26 macam produk unggulan daerah. Dari kontribusi data yang di cover dari Disperindag Kota Solo menunjukkan bahwa, muncul paparan kriteria Kesepakatan 7 produk prioritas unggulan bagi kota Solo, yaitu; Batik dan produk Batik, Tekstil dan Produk tekstil, Makanan, Percetakan, Plastik, Mebel dan logam/besi (2007).

Suatu alasan mengapa prioritas produk unggulan yang terpilih adalah produk-produk tersebut adalah; (1) dapat menyerap tenaga kerja yang banyak (2) nilai produksinya tinggi (3) image tentang produk tersebut adalah menjadi trade-mark bagi kota Solo. Dari 7 prioritas produk unggulan daerah kota Solo selanjutnya dimunculkan produk unggulan utama yang menjadi pertimbangan penentuan kriteria untuk memunculkan produk inti unggulan Kota Solo yaitu: Batik dan Produk Batik.

Langkah selanjutnya adalah melakukan uji kuesioner dan diskusi dengan narasumber kompeten yang memiliki kewenangan serta konsern terhadap produk kompetensi daerah. Selanjutnya dilakukan kriteria pembobotan, di mana memunculkan suatu produk kompetensi unggulan dengan komponennya seperti; keterampilan staf, manajemen brand, daya inovasi, kesetiaan kerja, jaminan kualitas, desain, tenaga kerja banyak, sumber daya lingkungan yang tidak merusak, manajemen harga, daya adopsi, manajemen jaringan dan lain sebagainya.

\section{Peta Rantai Nilai Produk Unggulan Prioritas}

Produk kompetensi unggulan prioritas ditemukan dari kompetensi-kompetensi produk unggulan yang telah diidentifikasi. di mana kriteria pemilihannya adalah dengan mempertimbangkan:

- Keunikan

- Daya saing

- Keterbukaan terhadap pasar baru

- Manfaat yang lebih baik bagi pelanggan

Berdasarkan kategori kompenen-kom-

Tabel 4. Matriks Keputusan Ranking Produk Unggulan

\begin{tabular}{llcccccc}
\hline & \multicolumn{6}{c}{ Kriteria } \\
No & $\begin{array}{c}\text { Alternatif Produkl } \\
\text { Industri }\end{array}$ & $\begin{array}{c}\text { Nilai } \\
\text { Produksi }\end{array}$ & $\begin{array}{c}\text { Investasil } \\
\text { Unit }\end{array}$ & $\begin{array}{c}\text { Jml } \\
\text { Tenaga } \\
\text { Kerja }\end{array}$ & $\begin{array}{c}\text { Preferensi } \\
\text { Nara } \\
\text { Sumber }\end{array}$ & $\begin{array}{c}\text { Nilai } \\
\text { Alternatif }\end{array}$ & Peringkat \\
\hline & Bobot Kriteria & $\mathbf{0 , 3}$ & $\mathbf{0 , 2}$ & $\mathbf{0 , 2}$ & $\mathbf{0 , 3}$ & $\mathbf{1}$ & \\
1 & Batik dan Produk Batik & 5 & 3 & 2 & 4,728708045 & 3,918612414 & 1 \\
2 & Logam/Besi & 1 & 1 & 1 & 2,956154917 & 1,586846475 & 7 \\
3 & Makanan & 4 & 2 & 3 & 4,472135955 & 3,541640786 & 3 \\
4 & Mebel & 1 & 5 & 1 & 3,590938482 & 2,577281545 & 6 \\
5 & Percetakan & 3 & 4 & 4 & 3,109843949 & 3,432953185 & 4 \\
6 & Plastik & 2 & 5 & 5 & 1,414213562 & 3,024264069 & 5 \\
7 & Tekstil dan Produk & 5 & 1 & 5 & 3,827710282 & 3,848313085 & 2 \\
\hline
\end{tabular}

Sumber: hasil penghitungan dengan analisis Bayes dari data primer dan sekunder 
ponen tersebut akhirnya penentuan kriteria, memunculkan Batik dan produk batik sebagai produk kompetensi unggulan Kota Solo.

Melalui penghitungan Analytic Hierarchy Process ditemukan bahwa pada batik dan produk batik memiliki in-konsistensi nilai bervariasi antara 0,1 hingga sampai 0,09. Artinya dari kajian analisis ditemukan semua kriteria dan kompetensi batik dan produk batik memiliki manfaat kepentingan yang ideal sesuai dengan harapan dari produk kompetensi unggulan prioritas kota Surakarta.

Dari kajian analisis ditemukan semua kriteria dan kompetensi unggulan batik dan produk batik memiliki manfaat kepentingan yang ideal sesuai dengan harapan dari produk unggulan prioritas kota Surakarta. Tabel 5 menunjukkan kriteria kompetensi unggulan prioritas batik dan produk batik yang memiliki kriteria-kriteria paling menonjol adalah dari sisi keunikan memiliki skor 0,356 serta sisi daya saing dengan skor 0,226. Sedangkan kriteria unik dimungkinkan dapat muncul karena produk ini memiliki suatu nilai lebih dan tidak mudah ditiru, sedang daya saing disini produk tersebut apabila diperbandingkan dengan produk sejenis memiliki kelebihan layak jual laku keras di pasaran.

Kriteria produk unggulan batik dan produk batik memiliki in-konsistensi relatif baik sebesar 0,09 masih kurang dari 0,1 sedang skor pembobotan dari masing-masing kriteria yang ada berkisar antara 0,102 sampai 0,356 .
Tabel 5. Kriteria Prioritas Kompetensi Unggulan Batik dan Produk Batik

\begin{tabular}{clc}
\hline No & Goal/Kriteria & Skor Bobot \\
\hline 1. & Unik & 0,356 \\
2. & Daya Saing & 0,226 \\
3. & Kekuatan & 0,169 \\
4. & Manfaat & 0,147 \\
5. & Keterbukaan & 0,102 \\
\hline
\end{tabular}

Keterangan: Inconsistency ratio 0,09

Tabel 6. Produk Unggulan Batik dan Produk Batik dengan Kriteria Unik

\begin{tabular}{clc}
\hline No & Goal/Kompetensi & $\begin{array}{c}\text { Skor } \\
\text { Bobot }\end{array}$ \\
\hline 1. & Karakteristik & 0,215 \\
2. & Desain & 0,211 \\
3. & Manajemen jaringan Distribusi & 0,199 \\
4. & Manajemen Brand & 0,142 \\
5. & Keterampilan Staf & 0,119 \\
6. & Disiplin Pekerja & 0,059 \\
7. & Daya Inovasi & 0,055 \\
\hline
\end{tabular}

Keterangan: Inconsistency ratio 0,02

Unggulan batik dan produk batik dengan kriteria unik ini memiliki kompetensi utama yang cukup baik dan kuat pada karakteristik dengan bobot 0,215 dan desain dengan bobot 0,211 yang memiliki in-konsistensi 0,02

Tabel 7. Produk Unggulan Batik dan Produk Batik dengan Kriteria Daya Saing

\begin{tabular}{clc}
\hline No & Goal/Kompetensi & Skor Bobot \\
\hline 1. & Daya Inovasi & 0,348 \\
2. & Desain & 0,173 \\
3. & Keterampilan Staff & 0,126 \\
4. & Jaminan Kualitas & 0,124 \\
5. & Manajemen Brand & 0,091 \\
6. & Tenaga kerja banyak & 0,074 \\
7. & Kesetiaan pekerja & 0,064 \\
\hline
\end{tabular}

Keterangan: Inconsistency ratio 0,09

Unggulan batik dan produk batik dengan kriteria daya saing memiliki kriteria dominan di kompetensi utama pada daya inovasi dengan bobot sebesar 0,348 dan desain 
dengan bobot sebesar 0,173 dengan rasio inkonsistensi 0,09.

Tabel 8. Produk Unggulan Batik dan Produk Batik dengan Kriteria Keterbukaan

\begin{tabular}{clc}
\hline No & Goal/Kompetensi & Skor Bobot \\
\hline 1. & Daya Inovasi & 0,260 \\
2. & Manajemen harga & 0,251 \\
3. & Daya Adopsi & 0,162 \\
4. & Disiplin Pekerja & 0,107 \\
5. & Keterampilan Staf & 0,099 \\
6. & Desain & 0,068 \\
7. & SDA melimpah & 0,053 \\
\hline
\end{tabular}

Keterangan: Inconsistency ratio 0,05

Demikian juga di unggulan batik dan produk batik dengan kriteria keterbukaan pasar, memiliki kompetensi intu utama dalam daya inovasi dengan bobot 0,260 dan kompetensi manajemen harga dengan skor bobot 0,251 dengan rasio in-konsistensi 0,05.

Hasil analisis Analytic Hierarchy Process selanjutnya mencoba memaparkan kompetensi unggulan untuk batik dan produk batik, dengan kriteria manfaat akan memliki kompetensi utama/kuat di manajemen harga dengan bobot sebesar 0,355 dan daya adopsi dengan bobot sebesar 0,257 . dengan rasio inkonsistensi 0,04.

Tabel 9. Produk Unggulan Batik dan Produk Batik dengan Kriteria Manfaat

\begin{tabular}{clc}
\hline No & \multicolumn{1}{c}{ Goal/Kompetensi } & Skor Bobot \\
\hline 1. & Manajemen harga & 0,355 \\
2. & Daya Adopsi & 0,257 \\
3. & Tenaga kerja banyak & 0,125 \\
4. & Daya Inovasi & 0,108 \\
5. & Desain & 0,064 \\
6. & Manajemen Brand & 0,047 \\
7. & Manajemen Jaringan Distribusi & 0,045 \\
\hline
\end{tabular}

Keterangan: Inconsistency ratio 0,04
Dianalisis unggulan batik dan produk batik dengan kriteria kekuatan ternyata memiliki kompetensi kuat/utama pada sisi karakteristik di mana memiliki bobot sebesar 0,292 dan desain dengan bobot sebesar 0,181 . Karakteristik batik Solo motifnya sangat tradisional, batik Solo dari warna, motif punya karateristik dan kualitas lebih bagus dari daerah lain di Indonesia. Demikian pula dalam rasa desain, batik dan produk batik Solo sama dengan daerah lain, hanya saja batik Solo memiliki motif unggulan corak klasik yang memiliki cita rasa makna tersendiri.

Tabel 10. Produk Unggulan Batik dan Produk Batik dengan Kriteria Kekuatan

\begin{tabular}{clc}
\hline No & Goal/Kompetensi & Skor Bobot \\
\hline 1. & Karakteristik & 0,292 \\
2. & Desain & 0,181 \\
3. & Manajemen jaringan Distribusi & 0,145 \\
4. & Manajemen Brand & 0,125 \\
5. & Keterampilan Staf & 0,107 \\
6. & Disiplin Pekerja & 0,103 \\
7. & Daya Inovasi & 0,046 \\
\hline
\end{tabular}

Keterangan: Inconsistency ratio 0,1

Batik dan produk batik Solo sebenarnya sama dengan daerah lain, sungguhpun demikian batik dan produk batik Solo memiliki motif kompetensi unggulan produk dengan corak klasik, terasa sangat kental makna filosofis.

Dari hasil penelitian lapangan yang dilakukan penelitian ini menunjukkan bahwa batik dan produk batik Solo diutamakan pada:

1. Karakter, desain serta daya inovasi di mana hal ini merupakan unsur dominan bagi andalan batik dan produk batik tulis dan cap Solo, 
2. Sumber daya manusia dengan kriteria banyak; seperti disiplin kerja serta keterampilan staf yang baik,

3. Daya saing akan dapat memiliki kompetensi unggulan yang ditunjang dengan manajemen harga relatif kompetitif serta manajemen jaringan distribusi yang baik

\section{Analisis Supply Chain Management pada Batik dan Produk Batik}

Menurut Schroeder (2000), supply chain management adalah strategi untuk merencanakan, mengelola dan mengawasi aliran barang-jasa dan informasi dari pemasok, perusahaan, distribusi sampai dengan konsumen akhir dengan kualitas yang terjaga sepanjang waktu. Secara sederhana sebuah Supply Chain Management dapat diringkas seperti nampak dalam Gambar 1.

\section{Aktivitas pendukung}

Aktivitas pendukung dalam sebuah rantai nilai terdiri dari empat aktivitas, yaitu antara lain kesetiaan kerja, manajemen brand, tenaga kerja yang banyak serta SDA yang tidak merusak. Bagi Batik dan Produk Batik Solo yang menjadi prioritas utama dalam rantai nilai aktivitas pendukung adalah sebagai berikut:

1. Kesetiaan Kerja secara teoritis adalah lamanya SDM bekerja di mana dalam usaha pembatikan dan produk batik pekerja memiliki suatu ciri unsur kese- tiaan/ketaatan kepada juragan/pengusaha dapat diatur dari turnovernya. Hubungan spesifik antara majikan dan pekerja ini memberikan dampak positif terwujudnya daya saing yang kuat bagi batik dan produk batik di daerah kota Surakarta. loyalitas pekerja batik sangat tinggi, karena mereka bekerjanya mengandalkan perasaan dalam hal mendesain sampai mengerjakan proses produksi hanya memang karena tingkat pendidikan yang tidak begitu tinggi, agak susah dalam mengatur disiplin kerja mereka, ini menyangkut tingkat pendidikan yang relatif kurang. Proses pembatikan apalagi batik tradisional sampai modern, SDMnya menggunakan banyak perasaan, sungguhpun tingkat pendidikan relatif kurang tinggi, demikian itu tentunya perusahaan yang unggul akan dapat mengatur loyalitas dalam bentuk pengaturan waktu, misalnya dengan cara model pekerja borongan. Kalau menggunakan sistem part time nampaknya sulit untuk dikerjakan. Karena proses pembatikan ini akan berbeda dengan di tekstil.

2. Manajemen Brand, adalah penggunaan merek dan pengelolaannya adalah merupakan suatu wujud pencitraan bagi produk batik, yang dapat memberikan sentuhan nilai tambah batik dan produk batik Solo. Ternyata batik Solo memiliki karakter sendiri di mata konsumennya. Batik Solo secara tidak langsung sudah memiliki keungulan karena Solo merupa-

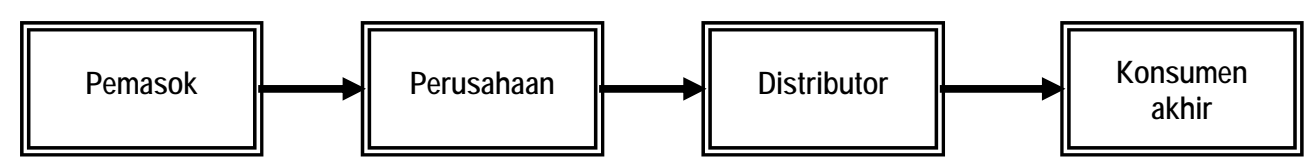

Gambar 1. Supply Chain Management 
kan salah satu daerah penghasil produk batik besar di Indonesia. Image nama lama sampai sekarang masih dominan mempengaruhi pencitraannya bagi konsumen. Banyak orang-orang dari luar daerah Surakarta memiliki cita rasa bahwa batik itu ya,... adanya di Solo. Branding batik Solo dapat dikatakan memiliki sisi unggul.

3. Tenaga kerja yang banyak adalah merupakan jumlah tenaga kerja dalam industri batik dan produk batik.. Berdasarkan hasil FGD kompetensi tenaga kerja dalam kaitannya dengan produk batik IKM di Kota Surakarta relatif cukup besar mengingat tenaga kerja di lingkup pembatikan ini memiliki keterkaitan dengan penyerapan tenaga kerja di sektor lain di mana ada tenaga kerja yang berlainan sifatnya. Batik dapat menyerap TK di bahan material dan. proses prapembatikan ternyata sudah dapat membu- ka peluang tenaga kerja di sektor/industri yang lain.

4. SDA di sini adalah merupakan sumber daya alam yang ramah lingkungan, sifatnya tidak merusak. Batik dan Produk batik memerlukan komponen hasil olahan dari SDA seperti gondorukem serta bahan pewarna alam. Gondorukem diambil getahnya tetapi pohonnya tetap dilestarikan, sedang bahan pewarna alam diambil dari sulur-sulurnya atau daundaunnya eksistensi pohonnya tetap dilestarikan.

Peta Rantai Nilai (Chain Map) Produk Unggulan Prioritas peringkat pertama yang terindikasi di wilayah Kota Surakarta, yaitu Batik dan Produk Batik, Dengan spesifikasi batik tulis dan batik cap, dalam bentuk bagan skematis sederhana dapat dideskripsikan seperti dalam Gambar 2.

Aliran barang dan jasa serta informasi dalam IKM komponen batik dan produk

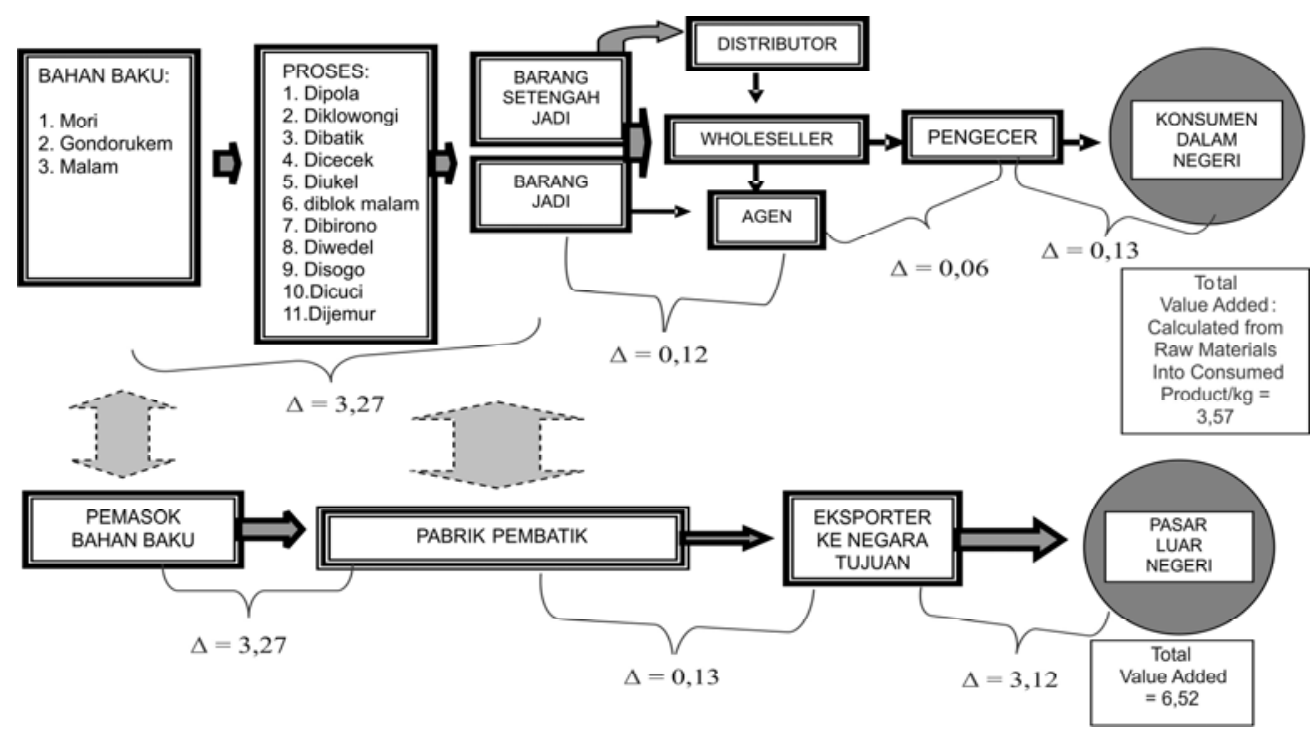

Gambar 2. Simulasi Analisis Ekonomi Peta Rantai Nilai dan Nilai Tambah (Added Value) Kompetensi: Batik Tulis dan Batik Cap 
batik di Kota Surakarta belum sempurna. Hal ini dikarenakan dari komponen Supply Chain Management IKM pembatikan di Surakarta terkonsentrasi sebagian besar di wilayah Kecamatan Laweyan dan Kecamatan Pasar Kliwon, utamanya di Kampung Laweyan dan Kampung Kauman Pasar Kliwon, serta sebagian di daerah Kampung Sewu.

Para pelaku IKM batik dan produk batik ini hanya menguasai aliran barang dan jasa serta informasi di tingkat perusahaan/pabrik/ bengkel kerja, sementara untuk pasokan bahan baku seperti; malam/lilin, obat batik (terbuat dari bahan baku alamnya Gondorukem dan pewarna alam yang didapat dari pohonan yang diambil sulur atau daunnya) dan juga distribusi, menunjukkan kondisi ketergantungan mereka pada pihak lain sangat besar, sungguhpun persediaan bahan cukup memadai.

Idealnya dalam sebuah industri pembatikan yang berdaya saing tinggi maka setiap komponen dalam Supply Chain Management bisa dikontrol atau diantisipasi terutama dari aliran informasi. Semakin lemah kontrol perusahaan, pabrik atau bengkel kerja pembatikan seperti di kota Solo terhadap informasi dalam mata rantai Supply Chain Management, maka industri kecil menengah pembatikan di daerah Solo akan semakin rentan dengan ketidakpastian.

\section{KESIMPULAN}

1. Batik dan produk batik yang memiliki peringkat pertama dalam produk unggulan industri kecil menengah di kota Surakarta atau Solo yang memiliki keunikan dalam motif, sungguhpun motif yang ada sangat banyak, tetapi memiliki kompetensi unggulan dominan dalam karakteristik, desain dan daya inovasi, serta makna filosofis atas motifnya.

2. Batik dan produk batik kota Solo dalam proses pengerjaannya memerlukan kemampuan teknik membatik yang baik. Itulah sebabnya mengapa batik dan produk batik tulis dan cap Solo dikatakan memiliki keunikan, karena mampu bersaing dengan kompetitor di daerah/ wilayah Indonesia lainnya, buktinya batik Solo masih eksis sampai saat ini.

3. Batik dan produk batik kota Solo memiliki pangsa pasar Asia, Amerika, Afrika serta Eropa. Untuk pangsa pasar Amerika, Afrika dan Eropa, Batik yang diinginkan batik bermotif sederhana, yang penting motif gambar pada kain tersebut dilakukan dengan proses batik.

4. Seiring dengan diadakannya mem-patent kan motif batik Solo, gelar acara Solo Batik Carnival, Srawung Batik, serta event-event yang berkaitan dengan promosi batik Solo, seyogyanyalah ada kajian lanjut dalam upaya pemberian ruang pas serta kebijakan yang perlu dari pemerintah daerah kota Surakarta dan instansi terkait lainnya, agar supaya batik dan produk batik tulis serta batik cap Solo benar-benar menjadi produk kompetensi unggulan nyata, bukannya produk semu yang dipaksakan.

Saran-saran yang diajukan dari penelitian ini sebagai berikut

Pertama, perlu dilakukan survey lapangan untuk memperoleh data yang sebenarnya mengenai persoalan kompetensi unggulan. Tidak hanya didasarkan pada data yang sudah ada di instansi tertentu. Data instansi hanya sebagai alat pengontrol saja. Kedua, Seharusnya jangan hanya menentukan pro- 
duk kompetensi unggulan IKM dari jenis barangnya saja tetapi, memasukkan juga produk jasa, karena di kota (kebanyakan kota besar) untuk produk unggulan IKM dari barang biasanya kurang bisa diandalkan. Sehingga perlu produk unggulan bersifat jasa, hal itu karena kebanyakan produk yang dihasilkan adalah jasa. Ketiga, membangun produk kompetensi unggulan bagi daerah diperlukan komitmen, kebijakan pemerintah dan asosiasi pengusaha/industri/bengkel kerja IKM.

\section{DAFTAR PUSTAKA}

Akita, Takahiro dan Armida S. Alisjahbana, 2001, The Economic Crisis and Regional Inequality in Indonesia, Makalah seminar, Jakarta.

Amurwaraharja, Indra Permana, 2003, Analisis Teknologi Pengolahan Sampah dengan Proses Hirarki Analitik dan Metoda Valuasi Kontingensi, Bogor: Program Pascasarjana IPB.

Azis, Iwan Jaya, 1997, Analytic Hierarchy Process, in the Benefit Cost Framework:

A Post Evaluation of the Trans Sentra Highway Project, European Journal of Operation Research, 48 (1990): 38-48 North Holland.

Badan Pusat Statistik. tt. Surakarta dalam Angka, Surakarta: BPS Kanwil Surakarta.

Blodger's Communications, tt. Analytic Hierarchy Process (AHP), Tutorial, RFID.

Disperindag. 2007. Rencana Pengembangan Industri di Surakarta. Surakarta: Bagian Penerbitan Disperindag.
Disperindag. tt. Laporan Data Industri Daerah, Surakarta: Disperindag Kota Surakarta.

Garcia dan Soelistianingsih, 1998, Pengaruh Variabel Modal Manusia, Fertilitas Total, Selain Pangsa Sektor Minyak dan Gas dalam PDRB untuk Mengukur Ketersediaan Sumber Daya Alam terhadap Pertumbuhan Ekonomi Daerah, Penelitian, Jakarta

Haeruman, 2000, Tantangan Bagi Dunia Usaha Pengembangan Industri Kecil

Indonesia Human Development Report, 2002, Regional Economics Development

Islam, Iyanatul, 2005, Ketidakmerataan Antardaerah di Indonesia, School of International Business and Asian Studies, Griffith University, Australia.

Kurniawan Bangun Nur Cahyo, 2006, Multicriteria Decision Making Methot for the Determination of Collection Priority of land and Property Tax (PBB) by Letter Force, Geodesi FTSL, ITB.

Porter, M. E. 1985. Competitive Advantage Creating and Sustaining Superior Performance. New York: The Free Press.

Porter, M. E. 1990. The Competitive Advantage of Nations. New York: Free Press.

Saaty, Thomas. L, 1989, Decision Making, Reading and Number Crunching, Decision Sciences 20 (2).

Saaty, Thomas. L, 1993, Pengambilan Keputusan bagi para Pemimpin, Proses Hirarki Analitik untuk Pengambilan Keputusan dalam Situasi yang Kompleks, Manajemen No.14, Jakarta: PT. Pustaka Binaman Pressindo. 
Schroeder, 2000, Supply Chain Management, New York: PrenticeHall.

Subekti, Nanang, 2005, Pertumbuhan Ekonomi Regional, Makalah Seminar, Jakarta.

Soebagiyo, Daryono, 2002, Perspektif Kota Surakarta dalam Wacana menjadikan Sebagai Ibukota Propinsi, Makalah Seminar Dialog Ekonomi Regional, IMM, Surakarta.

Soebagiyo, Daryono, 2001, Model Perencanaan Ekonomi Melalui Metode Pengambilan Keputusan dengan AHP (Analytic Hierarchy Process), Jurnal Ekonomi Pembangunan Vol 2. No.1 Juni 2001 Surakarta: BPPE FE UMS

Subagiyo, Daryono. 2007. Pengembangan UKM Yang Berdasarkan Kompetensi di
Kota Surakarta. Hasil Riset Diseminasi Pengkajian Kompetensi Inti Daerah. Surakarta.

Teknomo Kardi, Hendro Siswanto, Sebastianus Ari Yudhanto, 1999, Penggunaan Metode Analytic Hierarchy Process dalam Menganalisa Faktor-faktor yang Mempengaruhi Pemilihan Modal ke Kampus, Dimensi Teknik Sipil, Vol.1, No,1, Maret 1999, Universitas Kristen Petra, Surabaya.

World Bank, 2005, Indonesia Policy Briefs, Mendukung Usaha Kecil dan Menengah, Washington DC: The World Bank. 